\title{
The Kahana Valley Ahupua'a, a PABITRA Study Site on O'ahu, Hawaiian Islands ${ }^{1}$
}

\author{
Dieter Mueller-Dombois ${ }^{2}$ and Nengab Wirawan ${ }^{3}$
}

\begin{abstract}
The acronym PABITRA stands for Pacific-Asia Biodiversity Transect, a network of island sites and conservation professionals collaborating throughout the Pacific-Asia region. An ideal PABITRA site is a broad landscape transect from sea to summit. Such a landscape is Kahana Valley on Windward O'ahu. Kahana Valley served during prior centuries as an ahupua'a, a Polynesian unit of land management that integrated the three biological resource zones, the upland forests, the agriculturally used land below, and the coastal zone, into a sustainable human support system. Results of terrestrial biodiversity surveys, as begun with a vegetation/environment study and a paleoecological investigation, are presented in relation to historical land use and sea level changes. In spite of the many former human-induced modifications of the Kahana Valley landscape, the natural structure and function of its ecosystems are well preserved. The distribution patterns of vegetation can be interpreted in terms of Hawaiian ecological zones in combination with the valley's precipitation, topography, stream system, and archaeological features. Currently, efforts are under way to restore the Kahana State Park (recently renamed Ahupua'a 'O Kahana State Park) as a functional ahupua'a. In addition, focused collaborative research can yield helpful information for further restoration and integrated management of the Kahana ahupua'a as a historic Hawaiian Heritage Site.
\end{abstract}

The PABITRA (Pacific-Asia Biodiversity Transect) network aims to include broad landscape units with three interconnected biodiversity resource zones into a study program. The three resource zones are an upland or inland forest system that serves as watershed cover, the agroecosystems that are usually below in elevation, and the coastal zone ecosystems. A freshwater resource system is another essential component.

The objective is to study each of these ecosystem zones individually for their internal

\footnotetext{
${ }^{1}$ Manuscript accepted 20 April 2004.

2 Department of Botany, University of Hawai'i at Mānoa, 3190 Maile Way, Honolulu, Hawai'i 96822.

${ }^{3}$ Deceased, former Director, World Wide Fund, Indonesia.
}

Pacific Science (2005), vol. 59, no. 2:293-314

(C) 2005 by University of Hawai'i Press

All rights reserved functions but also to investigate their relationships as a landscape unit. The latter is necessary to ensure that the management of one resource zone does not affect the other zones negatively and that the zonation system is managed as an integrated landscape unit. Such is the management unit or human support system developed (through trial and error) by the early Hawaiians before contact with Western society and named ahupua'a.

\section{The Abupua'a Model}

An ahupua'a is an island landscape representing a vertical section from mountain to sea. It usually encompasses a watershed with the area to the sea as deep as a person can stand in the ocean water. Ahupua'a is a Hawaiian term. It refers to ahu, meaning a heap of stones, and pua'a, the Hawaiian word for pig. A related, second meaning of the term ahupua'a refers to an altar on which a pig was placed as a tribute to the chief or landowner for allowing the use of the ahupua'a land. The landlord or owner and manager of an 


\section{Ahupua'a (Typical Land Division)}

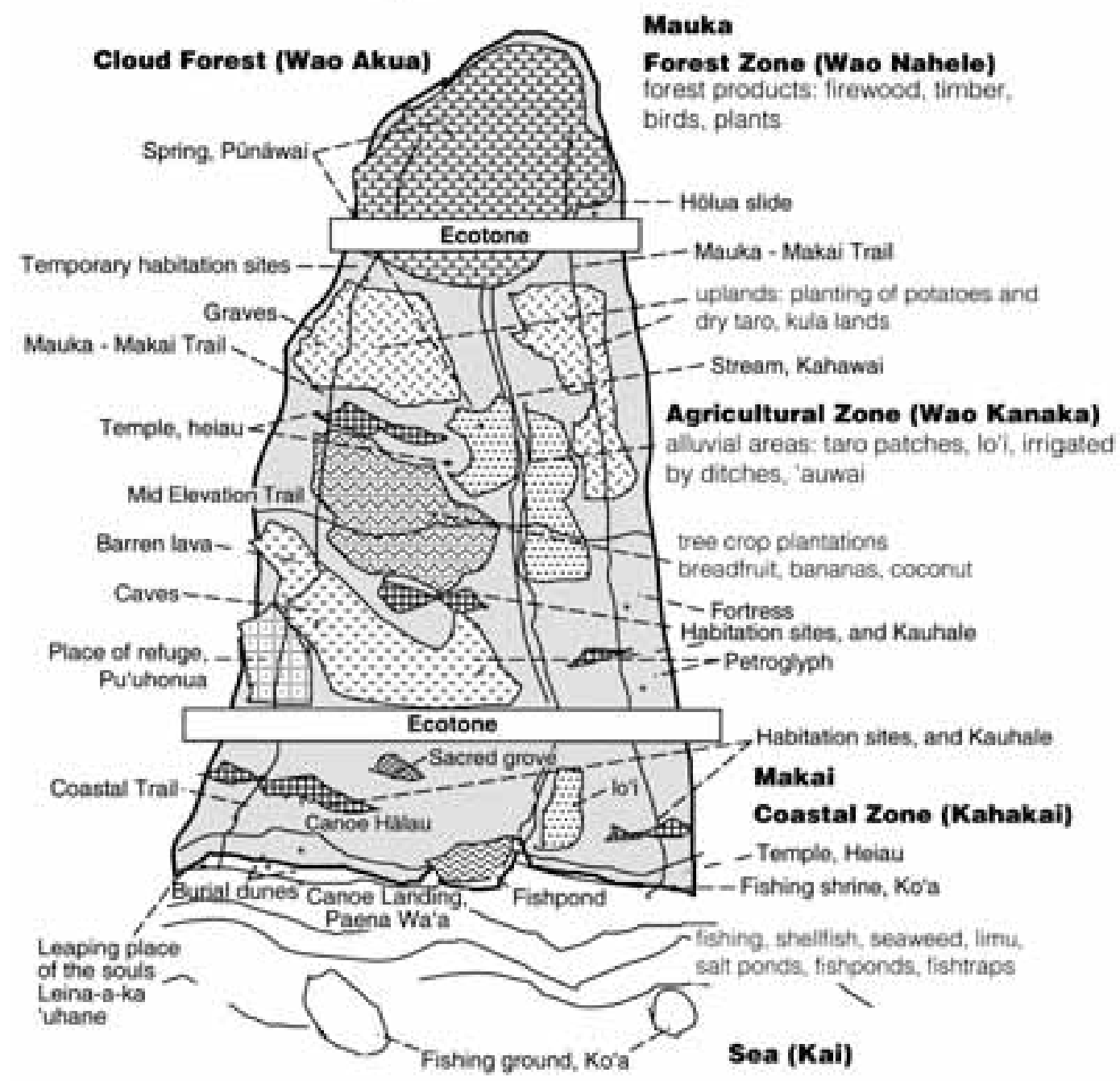

Figure 1. Ahupua'a model, after Minerbi (1999).

ahupua'a was called konohiki (Pukui and Elbert 1986).

Luciano Minerbi (1999) described a typical ahupua'a diagrammatically as here shown in Figure 1 with some slight modification emphasizing ecotones (i.e., transition zones). As seen here, an ahupua'a consists essentially of three vertically changing biological resource zones: the upland (mauka) forest zone (wao nahele), which may include a cloud forest (wao akua [akua means god]); the agricultural zone (wao kanaka [where people work]); and the coastal zone (makai or kahakai [kai means ocean, and kahakai means beach or seashore]). A fourth important resource zone, as shown on Figure 1, is the freshwater stream (kahawai). The stream flow is modified in the wao kanaka by man-made ditches ('auwai) 
for irrigating taro (Colocasia esculenta) patches (lo'i) on alluvial terraces. Dryland root crops, including taro and sweet potato ('uala, Ipomoea batatas), were grown in the opened-up uplands (kula uka). Breadfruit ('ulu, Artocarpus altilis), bananas (mai'a, Musa paradisiaca), and coconut (niu, Cocos nucifera) were among the most common tree crops planted in the lowlands and midlands.

Beyond crop areas, the ahupua'a contains makai-mauka (toward the sea-toward the mountain) access trails as well as midelevation and coastal trails, house sites (kauhale), temples (heiau), and burial sites ( $p \bar{a}$ ilina). A most important coastal resource enhancement includes a fishpond (loko i'a). This is a stonewalled enclosure in shallow coastal water that allows small fish to enter through sluice gates (mākāhā). After gaining in size, the fish is trapped. Thus, a fishpond acts as a large fish trap.

The two man-made devices, the irrigated terraces $\left(l^{6} \mathrm{i}\right)$ and fishponds, are clear evidence of the agricultural engineering talents of the early Hawaiians to make full use of the productive capacity of their windward ahupua'a.

\section{The Kahana Abupua'a and Its Tenure History}

LOcation. The Institute of Hawaiian Studies, University of Hawai'i at Mānoa, prepared a map of $\mathrm{O}^{\prime}$ ahu Island (Figure 2), which shows the traditional subdivisions into five districts, called moku, and numerous ahupua'a, all designated by names with boundaries. Kahana stands out on windward, central $\mathrm{O}^{\prime}$ ahu in the south of Ko'olauloa moku.

A recent photo taken from a low-flying aircraft (Figure 3) shows Kahana Valley with its restored fishpond at lower left (the Huilua Fishpond), the Kahana estuary next to it, its coastal ironwood (Casuarina equisetifolia) forest, the verdant central marsh, and forested bottomlands. The slopes show minor land scars, but are mostly forested. The peak on the left is Pu'u o Kila, $467 \mathrm{~m}$ (1,530 feet high), and in the background, about $6 \mathrm{~km}$ inland, is the Ko'olau mountain range with summit elevations of ca. $610 \mathrm{~m}$ (2,000 feet). Kahana Stream originates at about $300 \mathrm{~m}$ elevation behind the ridge extension of $\mathrm{Pu}^{\prime} \mathrm{u}$ o Kila. In front of the Pu'u o Kila ridge is Kawa Stream, which joins Kahana Stream in the midsection of the valley.

tenure history. The Kahana ahupua'a was originally a communal property of the Hawaiian people. It is estimated that from 720 to 1,000 indigenous people were living and supporting themselves from the resources of the valley and the ocean bay at the time of Western contact in 1776 (Stauffer 1990). Over the following $100 \mathrm{yr}$, the indigenous population declined to an estimated low of ca. 90 people. In the late nineteenth century, it rose again to ca. 250 inhabitants, primarily due to Chinese immigrants. Major factors for the rural decline of the indigenous people were introduced diseases, the lure of the city, Honolulu, and the great mahele (land division) of 1846-1855 with its ensuing privatization of native lands and the change to a foreign cash economy.

The great mahele resulted in a four-way division of the land. Recipients were (1) the king, (2) the other high ali'i, (3) the American-dominated government, and (4) the maka'ainana (the common people). Stauffer (1990) documented the changes in land tenure of Kahana Valley from 1846 to 1920. The great mahele allowed the maka'âinana to claim their kuleana (i.e., their house lots and cultivated areas). This amounted to only 200 acres (ca. 81 ha). The remaining uncultivated land, ca. 5,000 acres (ca. 2,024 ha), became the property of the high ali'i Annie Keohokālole in 1847. She was the mother of King David Kalākaua and his sister, Queen Lili'uokalani, who reigned from 1891 to 1893. Annie Keohokālole and her husband had large land holdings but little money. To support their lifestyle they needed money. Loans were given by foreign businessmen using land as security. Eventually, 3,000 acres (ca. 1,215 ha) of the ahupua'a were sold by Keohokālole to a Chinese merchant named Ah Sing in 1857. He became the konohiki. His son, Ah Mee, owned the property in 1872. Figure 4 shows Kahana Valley in a photo taken in 1888. Note absence of forest on foothills and presence of grazing animals.

The maka'āinana soon began to realize 


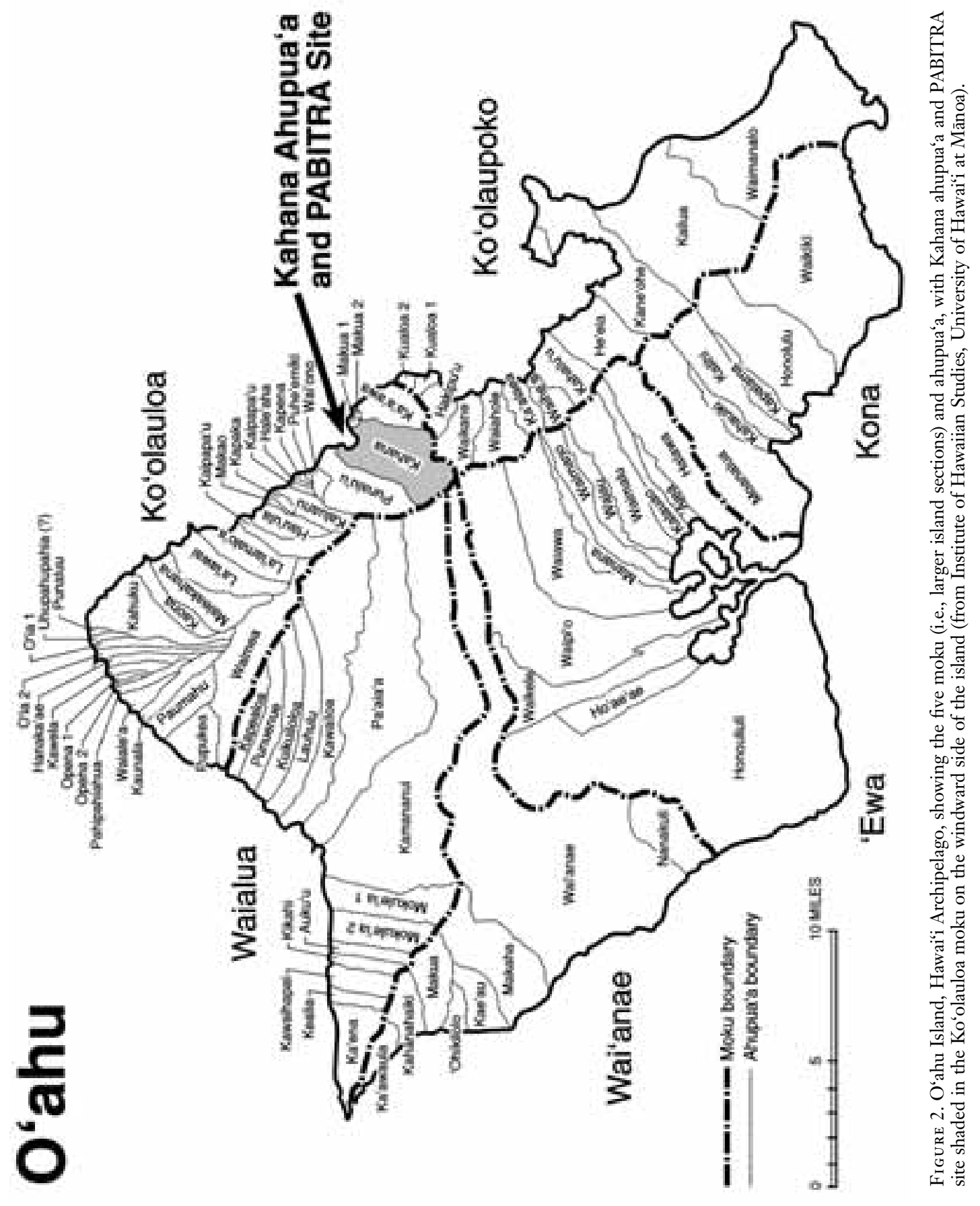




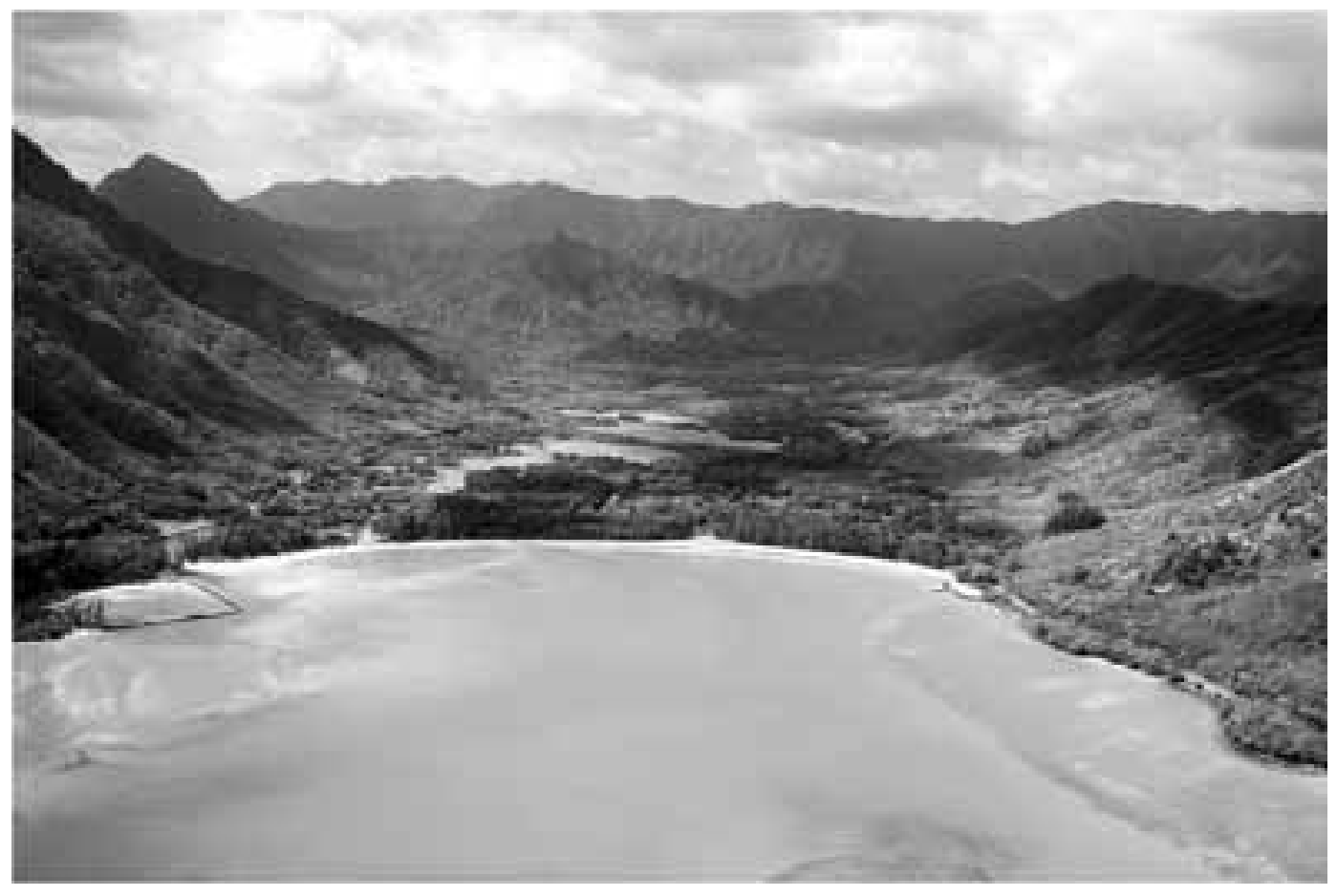

Figure 3. Kahana Valley as seen recently from a low-flying aircraft, with its restored fishpond at lower left (Huilua), the Kahana estuary next to it, the coastal ironwood (Casuarina equisetifolia) forest, the lush central marsh, land scars on frontal slopes, forested bottomland, and back slopes. Pu'u o Kila $(467 \mathrm{~m})$ stands out as the peak on the left horizon. Photo courtesy of Douglas Peebles.

that through privatization they lost their "cooperative rights" to the ahupua'a. These rights relate to using the uncultivated land with the freshwater stream that fed their lo'i via their ditch system (the 'auwai), the use of forest products and gathering rights as well as communal fishing rights.

In 1874 a Kahana hui (association) under George William Kamakaniau bought the Kahana ahupua'a back from Ah Mee for \$6,000. At that time, a Hawaiian again became the konohiki. However, the money was borrowed as a mortgage. This was made possible through the Mortgage Act of 1874. Eventually the mortgage terms could not be met by the Hawaiian hui, and foreclosure resulted in the transfer of ahupua'a property rights to non-Hawaiian businesspeople. Among these were the Castle family who owned the Kaneohe Ranch Co., and Mary Foster, daughter of the hapa haole (half foreigner) Robinson shipbuilder family. Mary Foster's husband, Thomas Foster, was a Canadian businessperson who owned interisland shipping, which later became the Matson Navigation Company.

Mary Foster was one-quarter Hawaiian, had close connections to the royal family, and spoke fluent Hawaiian. She eventually became the konohiki and prime owner of the Kahana ahupua'a by 1920. But she struggled with two other haole landowners, the Kaneohe Ranch Co. and the McCandless brothers. The Kaneohe Ranch Co. acquired a lease from the Hawaiian hui for Kahana's sloping uplands for cattle grazing. They burned much of the coastal upland and native midland forest for conversion into pastureland. The McCandless brothers acquired rights to the mauka uplands. As professional 


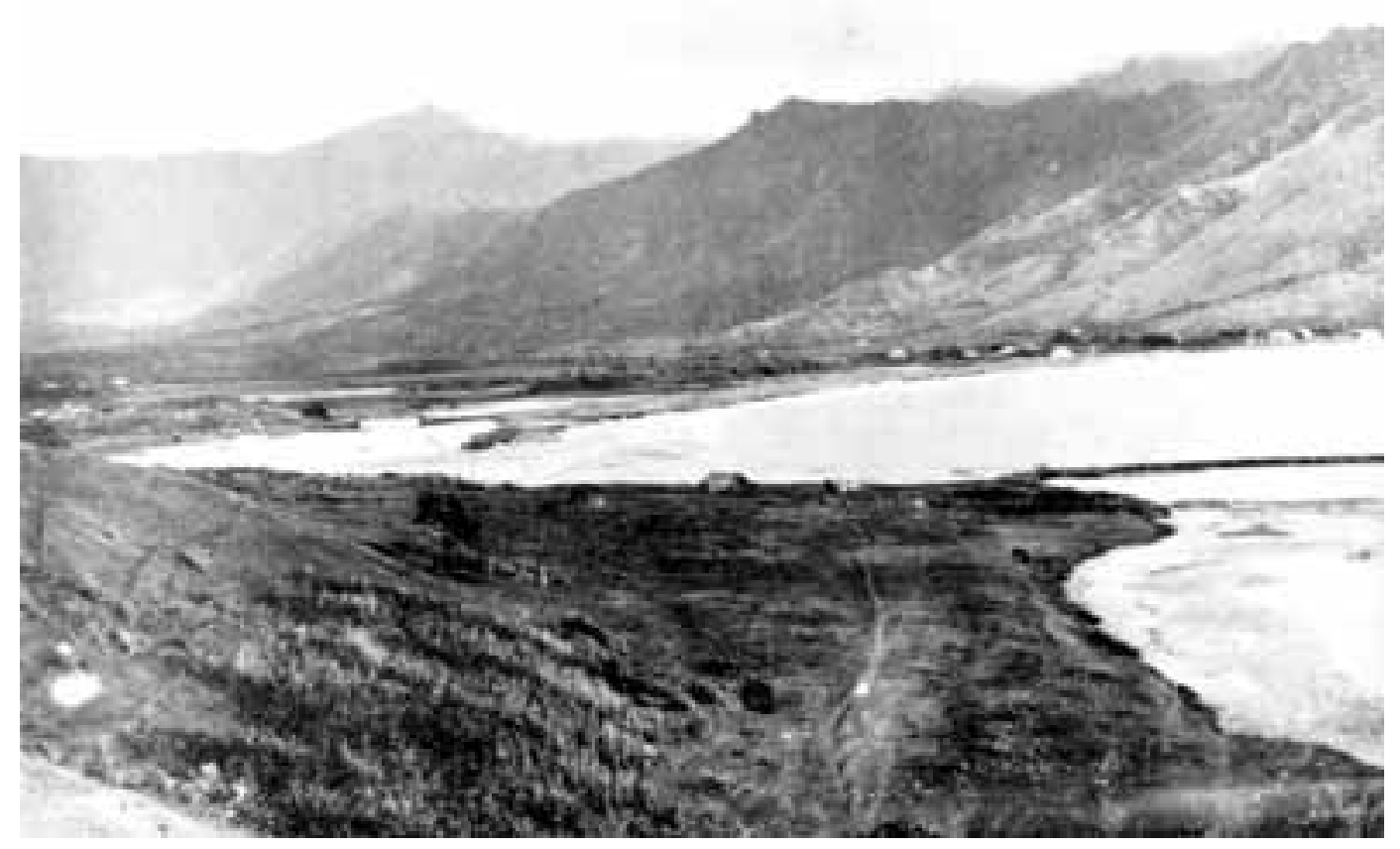

FIgURE 4. Frontal area of Kahana Valley in 1888 during time of ranching use. Grass and low scrub in foreground with grazing horses and almost barren slopes on opposite side of bay. Photo CP 96720, courtesy of Bishop Museum Archives.

artisan well borers, they realized the potential of tapping the windward groundwater resources halfway up the Ko'olau mountain range. They designed the Kahana-WaikāneWaiāhole Ditch and mountain tunneling system. The work was carried out by Asian miners from 1913 to 1916 . This was a great engineering accomplishment at that time, which made the irrigated sugarcane agriculture at 'Ewa basin possible. However, legal battles arose over the land and water rights with the konohiki of Kahana, Mary Foster. She received an out-of-court settlement, and the McCandless brothers made a fortune by selling their Waiāhole-Waikāne Water Co. to Amfac, owners of the O'ahu Sugar Co. in 'Ewa. Figure 5 shows the entrance to Kahana Valley from Kamehameha Highway and the Huilua Fishpond in a photo taken in 1936.

After Mary Foster's death, the Kahana ahupua'a reverted to the State of Hawai'i in
1967. It is now public property and called officially the Ahupua'a 'O Kahana State Park. Figure 6 shows the Kahana ahupua'a in a photo taken soon after World War II. Note the barren front hills and dry terraces (kula lands).

\section{Kahana Vegetation}

vegetation map. Nengah Wirawan prepared a vegetation map in 1972 (Figure 7) in conjunction with a botanical survey of Kahana Valley (Theobald and Wirawan 1973). He subsequently produced a Ph.D. dissertation (Wirawan 1978) on the vegetation ecology of Kahana under guidance of D.M.-D. At that time, the air photo-derived vegetation map was verified with 64 vegetation relevés (sample stands of $400 \mathrm{~m}^{2}$ each) spread out from the coastal area into the back of the valley up to the base of the steep 


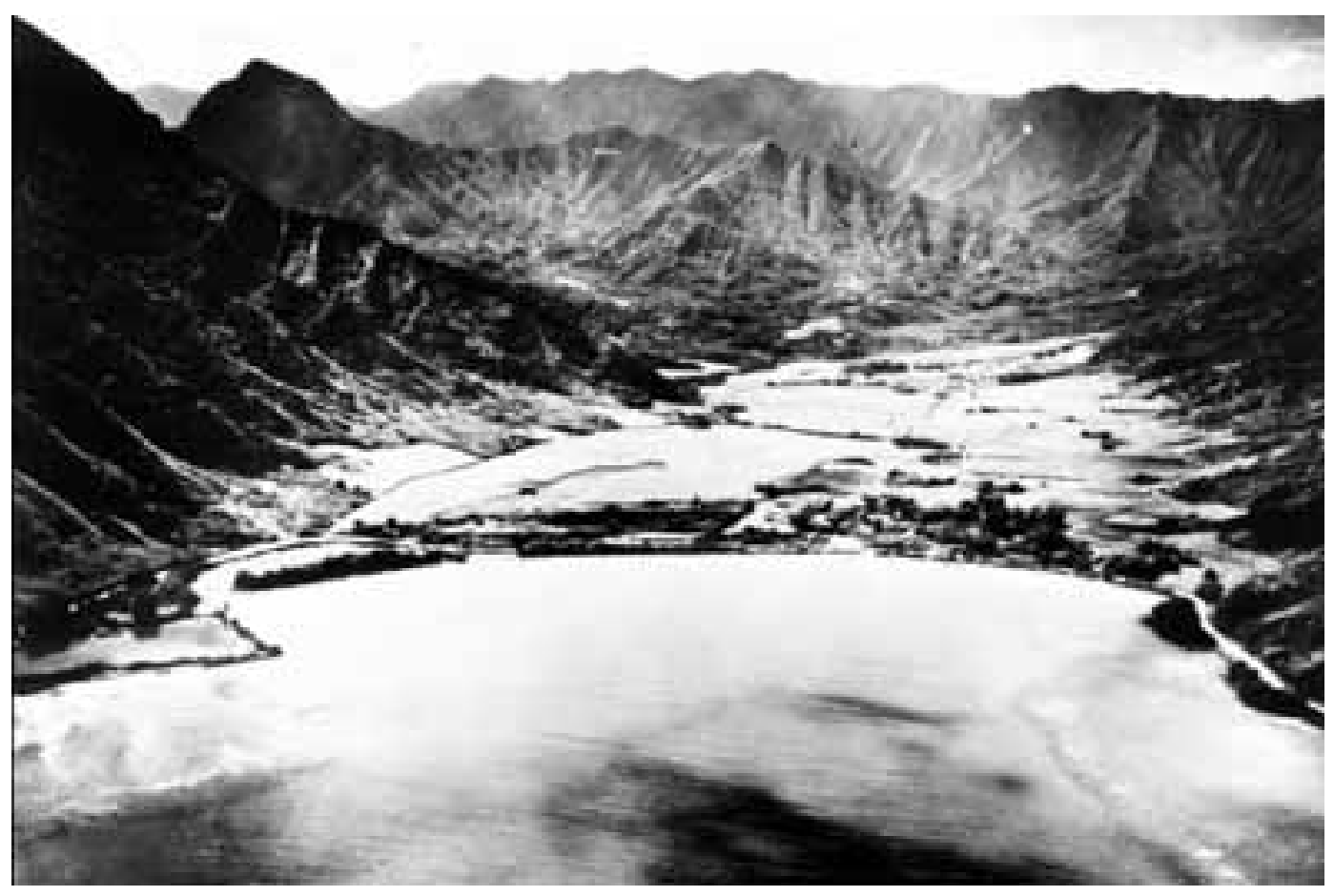

FIGURE 5. Kahana Valley in 1936 during Mary Foster's ownership. The valley was given to rice cultivation and cattle ranching. The Waikāne/Waiāhole Ditch and tunnel system was emplaced in the back of the valley. Photo 38215 AC, courtesy of Bishop Museum Archives.

wet cliff area where it rises from ca. 300 to $610 \mathrm{~m}$ over a short distance of ca. $200 \mathrm{~m}$. Figure 7 is a reproduction of Wirawan's vegetation map. It shows 13 units.

Unit 1 relates to the wet, sparsely vegetated, nearly vertical cliff area (pali) in the back of the valley. There are also pali segments on the eastern side, rendering Kahana an aging "amphitheater-headed valley." (For plants growing on wet and dry cliffs, see Mueller-Dombois and Fosberg 1998:488.)

Unit 2 is designated as Metrosideros woodland. The key species are clumps and scattered trees of Metrosideros polymorpha ('ohi'a lehua) together with the indigenous thick mat-forming uluhe fern, Dicranopteris linearis. Other important native trees are Eugenia sandwicensis (hā), Antidesma pulvinatum (hame), Psychotria (kōpiko), small stands of Pritchardia palms (loulu), and some Cibotium tree ferns (hāpu'u). Important aliens found in
1972 were occasional trees of Spathodea campanulata (African tulip tree) and the shrub Clidemia birta (Koster's curse).

Unit 3 represents an entirely alien tree planting of Paraserianthes falcataria, known commonly as the tall albizia legume tree. This tree planting indicates the Ko'olau Mountain ditch and tunnel system, developed between 1913 and 1916 for transferring some of the freshwater flow and the upper mountain-stored water for irrigating the former sugarcane fields in the 'Ewa basin above Pearl Harbor. The ditch system begins here in the upper Kahana back valley and continues through the neighboring Waikāne and Waiāhole ahupua'a to the south.

Unit 4 is recognized as the Acacia koaPandanus (hala tree) woodland. Both koa and hala are native trees. Most others are introduced. The latter include the Polynesian introduction Syzygium malaccense ('ōhi'a 'ai), 


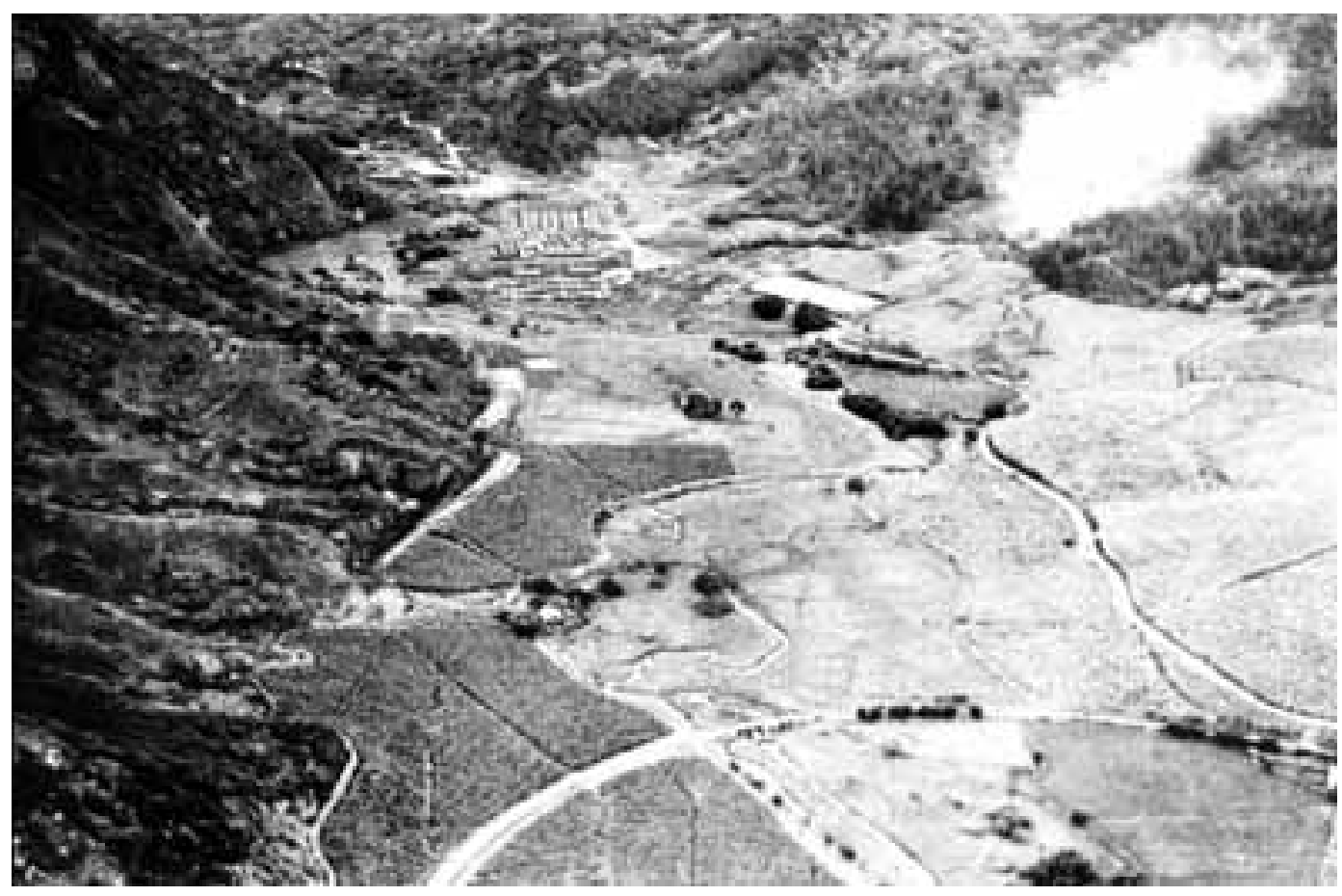

FIgURE 6. Kahana Valley in 1945 with sugarcane on lower left, open slopes above, smoke from a fire at right, and army installations above bottomland. Photo USA MH 5408, courtesy of Bishop Museum Archives.

which is common throughout the valley and well represented by seedlings and saplings, as well as an occasional Artocarpus altilis (the 'ulu or breadfruit tree). Other later-introduced fruit trees include the mango tree (Mangifera indica), guava or kuawa (Psidium guajava), and the strawberry guava or waiawi 'ula'ula $\left(P_{s i-}\right.$ dium cattleianum). The latter is considered a serious weed tree; there are some large (about $0.5-\mathrm{m}$ diameter) strawberry guava trees in Kahana Valley, signifying an introduction in the late 1800s. Seedlings and saplings are not abundant here. Instead, a new invader, Ardisia elliptica (the shoebutton tree), is rapidly becoming abundant in forest openings of unit 4. Koa saplings are sparse. Wirawan (1978) found that removal of the hala leaf litter and some soil surface scarification encourages koa regeneration in unit 4 . Some areas in this unit currently exhibit koa dieback or decline. A number of insects and fungal pathogens have been implicated but no causative rela- tionship has so far been ascertained (Puniwai 1997). The disturbance history is most likely involved. Abundant koa regeneration has been observed after fire (Judd 1935) or browser removal (Spatz and MuellerDombois 1973). After such events, koa regenerates in cohorts (i.e., generation stands). Once these cohort stands become senescent, any temporary climatic stress can trigger such tree groups into dieback because of their demographic predisposition. Insects and fungi often merely hasten the dieback or decline because such trees have lost their capacity to regenerate foliage. If these pest organisms were constantly virulent, trees would loose their foliage as soon as it forms. Of course, younger koa trees may also become predisposed to die (for example, in this case, through competition with hala trees, which have now gained dominance over koa in unit 4). Application of some sensible silviculture could reverse the trend. 


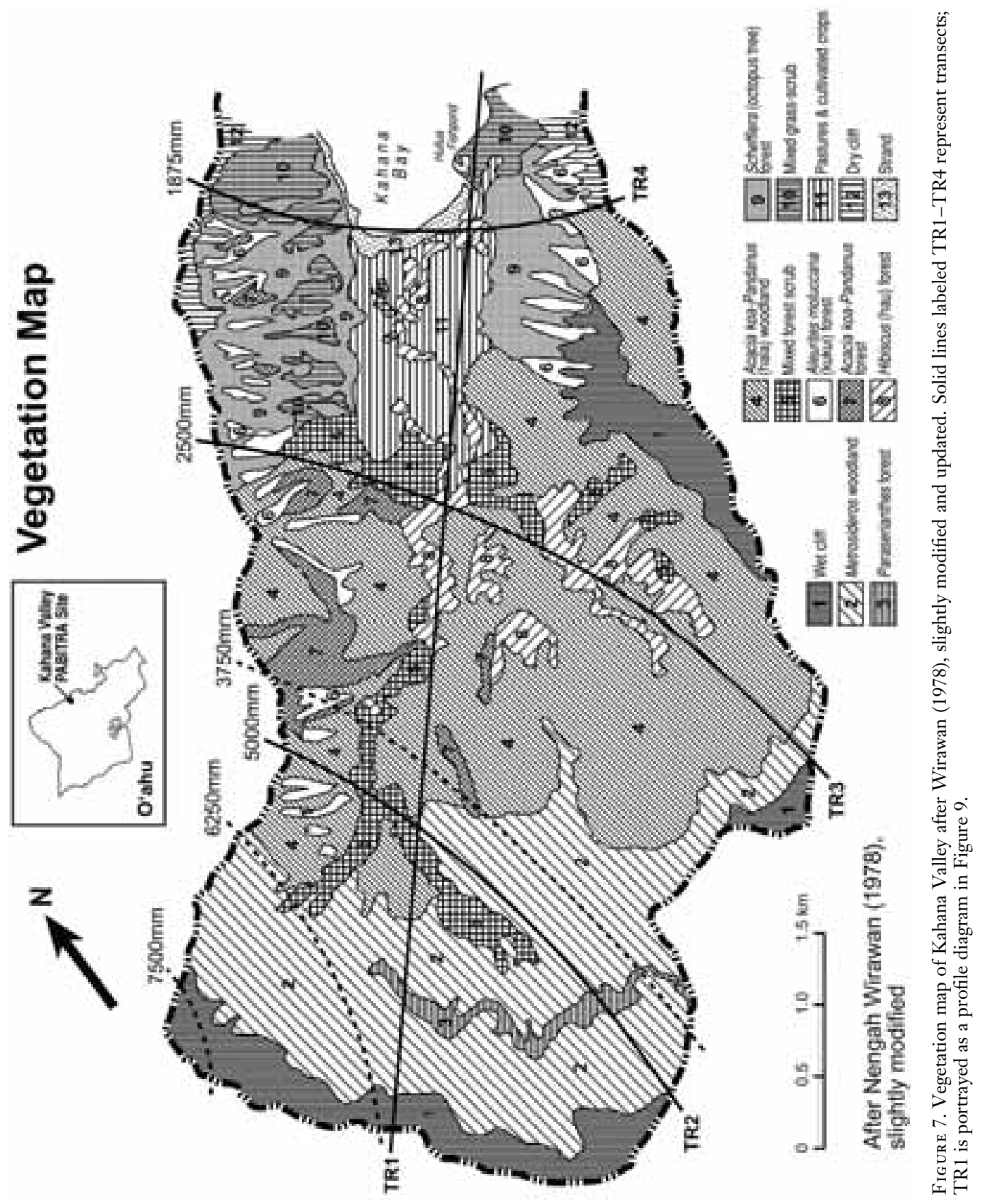


Unit 5 (crosshatched on the map), designated as forest scrub, consists primarily of small, pure-stand patches of Syzygium cumini (Java plum), Syzygium jambos (rose apple or 'ōhi'a loke), and stands of Phyllostachis nigra (black bamboo), and Schyzostachium glaucifolium ('ohe, possibly of Polynesian introduction). This unit grades into the riparian Unit 8.

Unit 6 is the Aleurites moluccana (kukui) tree community of Polynesian introduction. It fills the gulches on both the north and south slopes from near the coast to the middle of the valley. It is most prevalent in the mesic part of the valley and drops out where the mean annual rainfall exceeds $4,000 \mathrm{~mm}$. Wirawan (1978) found that kukui tree regeneration is related to storm surges, when tumbling rocks in the gulches happen to crack the accumulated kukui nuts on the forest floor.

Unit 7 is the Acacia koa-Pandanus forest, a variation of unit 4 , recognized by taller and denser tree growth indicating either a more productive habitat or less disturbed vegetation.

Unit 8 is dominated by the hau tree, $\mathrm{Hi}$ biscus tiliaceus, which is either native or another Polynesian introduction (Wagner et al. 1990). It forms a jungle or krummholz and covers many former irrigated terraces (lo $i$ i). It grows over sections of Kahana Stream and forms a dense cover all along its estuary. There it grows intermixed with the introduced American mangrove (Rhizophora mangle).

Unit 9 is occupied dominantly by the octopus tree (Schefflera actinophylla). It is a fastgrowing secondary rain-forest tree, probably introduced from Australia as an ornamental. Wagner et al. (1990) cited Degener as having said that the octopus plant was grown in pots and Hawaiian gardens as an ornamental in 1900. In Kahana, this tree has rapidly invaded the formerly open grass-covered slopes (kula kai) on both sides of the lower valley from the coast to about $1.5 \mathrm{~km}$ inland. It is now also invading the marsh (unit 11).

Unit 10, designated as mixed grass-scrub on the map, has now mostly disappeared. In 1972, this was dominantly occupied by Andropogon virginicus (the broomsedge), a py- rophytic grass introduced from the southeastern United States in 1924. Its spread was promoted by fire, and it contributed substantially to soil avalanching on slopes with deeply oxidized soil (ultisol) here in Kahana Valley and in many other windward valleys (Mueller-Dombois 1973). The grass-scrub cover is now mostly invaded by the octopus tree. However, a native shrub, Osteomeles anthyllidifolia ('ūlei), still prevails in the undergrowth on sun-exposed slopes, where Andropogon has become very sparse. The octopus tree is still on the move and currently is invading unit 4 farther inland as well as unit 11.

Unit 11 is primarily marsh-grassland of Brachiaria mutica (California grass). Like the broomsedge it was first collected in Hawai' $\mathrm{i}$ in 1924 (Wagner et al. 1990). At the time of mapping the marsh, which gets less swampy inland, this unit served as cow pasture, and in the wetter parts rice was still cultivated in the mid 1970s.

Unit 12 represents the dry coastal cliff community, sparsely vegetated with wisps of grasses including Heteropogon contortus (pili grass) and Rhynchelytrum repens (Natal redtop).

Unit 13 relates to the strand community, which at Kahana Bay is dominated by an ironwood (Casuarina equisetifolia) forest with a row of Terminalia catappa (kamani haole) trees along Kamehameha Highway. An updated plant checklist is included in the Appendix.

PHYSIOGRAPHIC ENVIRONMENT. Important geomorphic features of Kahana Valley are displayed on the physiographic map (Figure 8). The figure shows the physiography and topographical diversity by $200-\mathrm{ft}(61-\mathrm{m})$ contour lines. Steep slopes are indicated by crowding of the contour lines. The back valley rises steeply to the Ko'olau summit ridge. Another ridge, topped by the $1,530 \mathrm{ft}(467 \mathrm{~m})$ Pu'u o Kila, juts into the valley along the 5,000-mm precipitation line. A third ridge with a steep slope down into the valley is found on the east side near the coast. Wiggling of the contour lines indicates numerous steep gulches along each of the slopes, which from near the coast to beyond the midvalley 
are dominated by kukui, unit 6 on the vegetation map.

STREAM SYSTEM AND PRECIPITATION. The Kahana Stream system is shown in Figure 8 as originating in the back of the valley at about $1,000 \mathrm{ft}(305 \mathrm{~m})$ elevation. The dashed line running between $800(244 \mathrm{~m})$ and $1,000 \mathrm{ft}(305 \mathrm{~m})$ elevation indicates the ditch where fresh water is extracted for transfer to leeward $\mathrm{O}^{\prime}$ ahu. The freshwater stream system follows a course that relates directly to the topographic pattern of the valley. Another important feature is the precipitation gradient, which starts at the coast with a mean annual rainfall of $1,875 \mathrm{~mm}$ (74 in.). In the midvalley where Kawa Stream joins Kahana Stream, the mean annual precipitation is $2,500 \mathrm{~mm}$ (98 in.). From there rainfall doubles toward the back valley, where rainfall exceeds $7 \mathrm{~m}$ (275 in.) per year. Thus, there is a steep rainfall gradient. From the coast to the back valley rainfall increases from ca. $2 \mathrm{~m}$ to 7 $\mathrm{m}$ over a distance of $6 \mathrm{~km}$. The four physical environmental features of topography, geomorphology, stream system, and precipitation pattern explain much of the observed vegetation pattern.

TOPOGRAPHIC PROFILE WITH CLIMATE DIAGRAM. In addition, there is a gentle slope in the center of the valley, descending in steplike intervals from mauka to makai, as seen on the profile map along Transect 1 (Figure 9), which explains the direction of stream flow. The climate diagram substantiates the great differences in rainfall from mauka to makai. It also shows how rainfall is distributed throughout the year, indicating a short dry period in June/July at the coast versus monthly rainfall in excess of $300 \mathrm{~mm}$ inland at the Kahana Valley ditch and tunnel system. Here, one can see that it is also cooler by $1.5^{\circ} \mathrm{C}$ throughout the year.

HaWAIIAN ECOLOGICAL zones. The profile also shows an attempt to recognize the ecological zonation system developed by the early Hawaiians. It is here related to topography, precipitation, stream flow, and vegetation in five zones from mauka to makai. Zone A, kua mauna, refers to the wet cliff (pali) area in the back valley. Zone B, wao kele, refers to the wet Metrosideros forest.
Zone C, wao koa, relates to the Acacia koaPandanus area. Zone D, kula kai, refers to the formerly more open grassy slopes, now occupied mostly by introduced octopus trees. Zone E, kahakai, relates to the coastal strand, with Casuarina forest, mixed grass-scrub, and fishpond as well as into the sea up to about $1.5 \mathrm{~m}$ depth.

WATER Yield IN Kahana Valley. Takasaki et al. (1969) estimated the water yield for Kahana Valley. They calculated a total input from precipitation amounting to 60 million gallons (240 million liters) per day. This estimate appears reasonable. A relationship of height to area, which is easy to remember, is that $1 \mathrm{~mm} / \mathrm{m}^{2}$ yields 1 liter. If one considers the effective catchment area to be 2,000 ha (the Kahana ahupua'a is estimated to include 5,200 acres) and the average daily precipitation to be $12 \mathrm{~mm}$, the incoming yield would be $12 \mathrm{~mm} \times 2,000 \mathrm{ha}=240$ million liters or ca. 60 million gallons.

Takasaki et al. (1969) considered the following fractionation of their estimated 60 million gallons (240 million liters) input per day: 12 million gallons (48 million liters) are lost as evapotranspiration (20\%), 15 million gallons (60 million liters) are lost as runoff (25\%), 19 million gallons (76 million liters) enter the stream system (32\%), 4 million gallons (16 million liters) are removed by the Kahana-Waiāhole Ditch system (6\%), and 10 million gallons (40 million liters) leave the area as groundwater (17\%). This gives some idea of the valley's water yield potential. Further direct measurements at different rainfall events including storm surges and dry periods would be of considerable interest and practical value because this is known to be a highly dynamic relationship.

aRCHAEOLOGICAL MAP. Hommon and Barrera (1971) found 119 archaeological sites in Kahana Valley. They produced a foldout map that shows all of the site locations with an outline of their spatial extent. This map is here reproduced as Figure 10 and superimposed on the vegetation map units drawn at the same scale. The archaeological map shows that former human habitation sites extend about $5 \mathrm{~km}$ into the valley along the streams. The authors recorded 120 wet ter- 


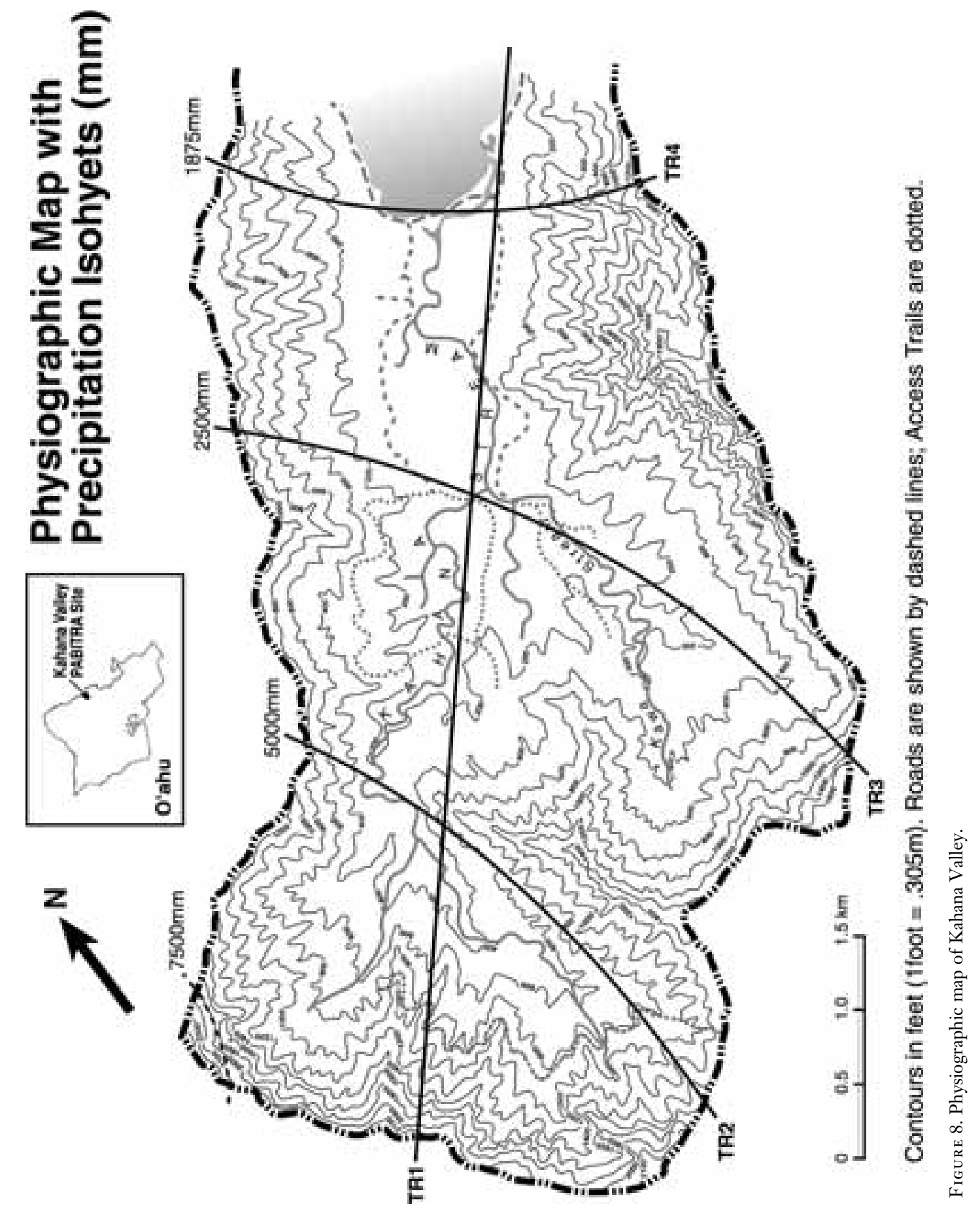




\section{Kahana Valley, Mauka/Makai Profile (Central) with Hawailan Ecological Zones (TR1)}

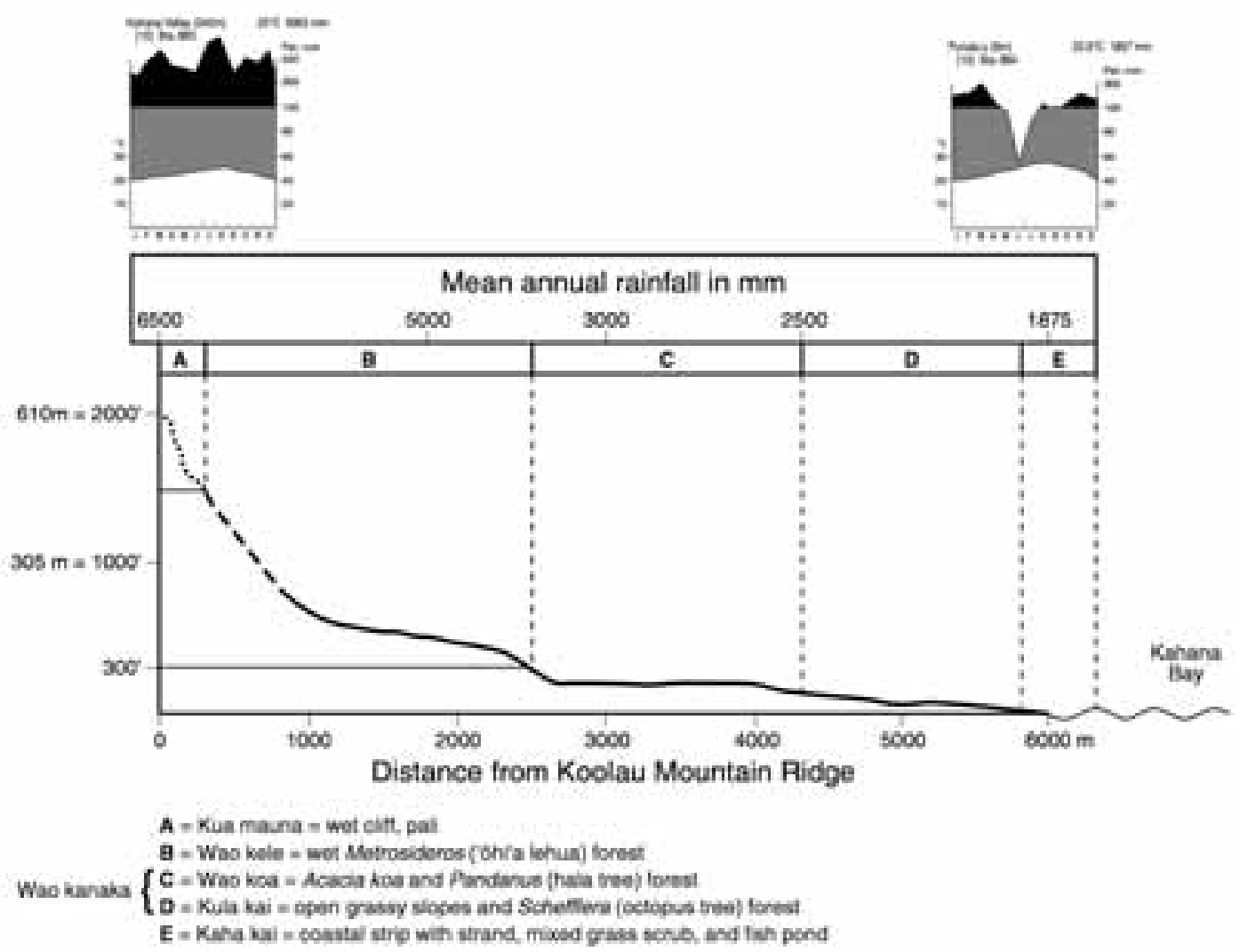

FigURE 9. Topographic profile from mountain to sea (mauka-makai) in central Kahana Valley following the course of Transect 1 (TR1) on the physiographic map (Figure 8). A Walter-type climate diagram (top right) shows mean monthly temperature and rainfall curves with a short dry season at the coast in June/July and year-round high rainfall in the back of the valley (top left) with a mean annual rainfall gradient from 1.9 to $5.9 \mathrm{~m}$ over $6 \mathrm{~km}$ distance from the coast to the back of the valley. Along this profile one can distinguish five Hawaiian ecological zones as indicated.

races (lo'i) connected by man-made irrigation channels ('auwai). Most of these terraces were built on gently sloping alluvial areas with retaining walls. The total growing surface of the wet terraces was calculated as $10,800 \mathrm{~m}^{2}$ (1.08 ha). The authors suggested that many lower terraces were probably buried under alluvial material. A second archaeological feature was clearings for the cultivation of nonirrigated crops (probably dry taro and sweet potato). These dry terraces were recognized by removal of stones. Terraces marked by stone walls were often rather small, only 2 by $10 \mathrm{~m}$. In addition, the authors identified animal enclosures, house sites, men's eating houses (mua), and scarcely legible petroglyphs. The archaeological sites coincide rather well with three current vegetation types, the mixed forest scrub (unit 5), the $\mathrm{Hi}$ biscus (hau) forest (unit 8), and the pasture and marsh (unit 11) as shown on the vegetation map. 


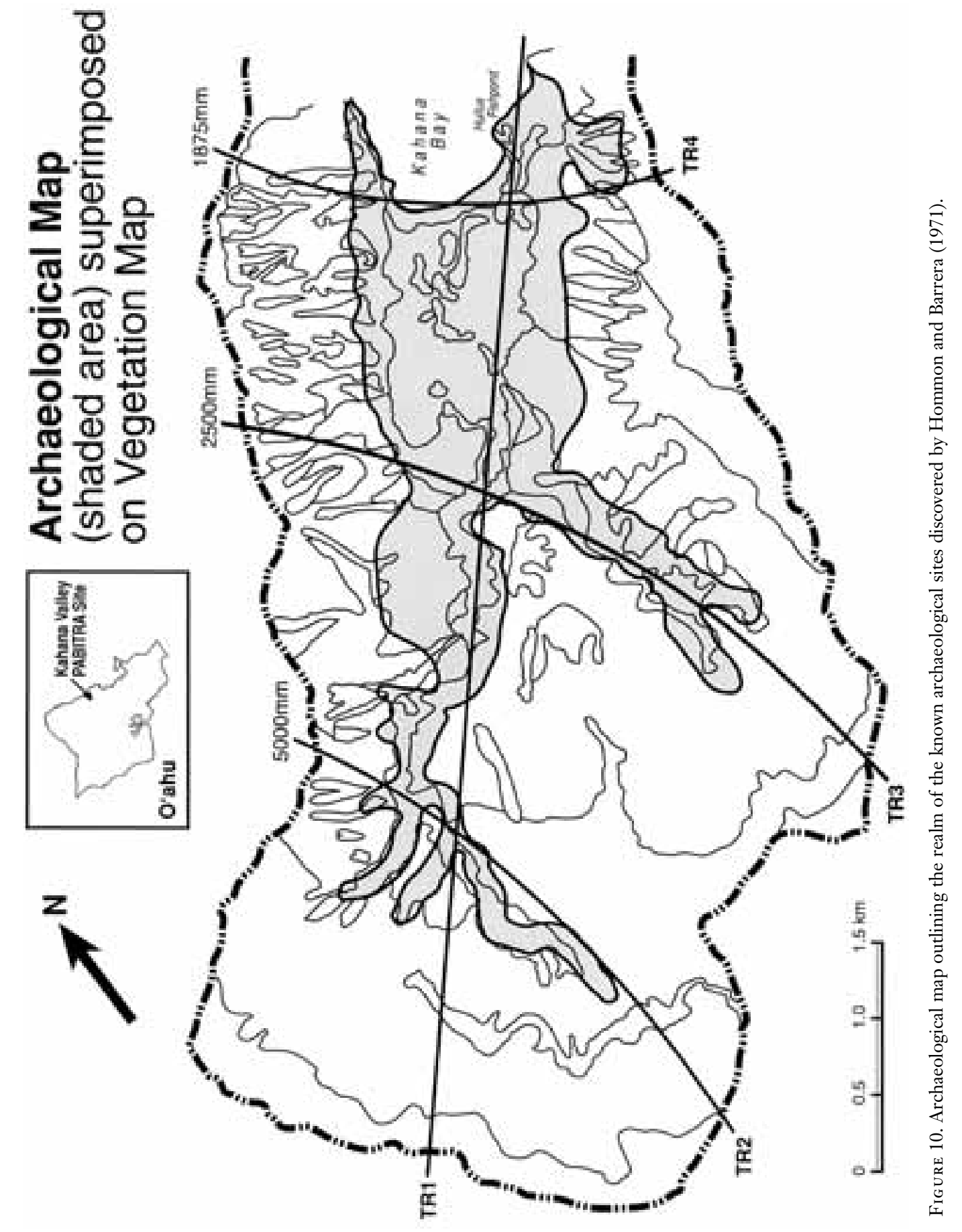




\section{Kahana Valley, a Geomorphic Artifact?}

A Former inland lagoon. Patricia Rice Beggerly (1990) presented a very thorough and thought-provoking Ph.D. dissertation on her paleoecological research in Kahana Valley. She considered Kahana Valley to be a "geomorphic artifact" based on past human impacts. She dug deep soil trenches in eight areas at the borders of the marsh and in the pasture up to $1.2 \mathrm{~km}$ inland. She used open trenches and auger borings to distinguish soil layers with inclusions of organic remains such as snail shells, charcoal, wood, pollen, and fern spores. For charcoal, shells, and some woody remains, she obtained radiometric dates. She distinguished seven soil strata from about $3 \mathrm{~m}$ depths upward to the current soil surface and clarified that the valley bottom was once an ocean inlet, a finding verified also for Kawainui marsh in the Kailua ahupua'a, farther south on windward O'ahu (see Kirch 1985). This was not surprising because there was a higher sea level following the Pleistocene. A shallow-water phase succeeded in the form of a lagoon. As evidence, Beggerly found shells of brackishwater snails, such as Tellima macoma dispar. In the lagoon phase, at the bottom of the marsh, she found charcoal. Dates for these organic remains turned out to be 430-30 в.с. Beggerly suggested that the charcoal remains argue for a first invasion of human settlers into Kahana Valley by at least 30 в.c. She believed that wood fires could not have started in this rain-forest valley because of its yearround high humidity. On the shallow lagoon bottom she found colluvial material as the next deposit upward. This material, she suggested, was deposited from the slopes by accelerated erosion, when the first human settlers used slash-and-burn swidden cultivation. Following the colluvial layer upward, mineral soil and organic muck mixtures indicate continued terrestrification. However, there was no charcoal inclusion until she came nearer to the surface (between 2.2 and $2.5 \mathrm{~m}$ ). The second find of charcoal was dated $1425 \pm$ 80 yr A.D.

PANDANUS VERSUS PRITCHARDIA POLLEN. Based on this second charcoal date, Beggerly
(1990) proposed that Kahana Valley was abandoned for at least 1,200 yr and was reinvaded by a new wave of indigenous settlers at about 1200 A.D. (i.e., 800 B.P.) at the earliest. She proposed that the earlier settlers, who came into the valley around $230 \pm 200$ в.c., experienced an "ecological crunch" due to their overexploitation of the valley's resources, with the ecological crunch having resulted primarily from their traditional slash-and-burn practice. This would have involved accelerated soil erosion and nutrient loss with slow growth of vegetation, thus shifting activity across the sloping landscape. This also implied exhaustion of readily available food resources, such as starch from treefern trunks and fish from the inland lagoon as it continued to decline from accelerated sedimentation. At that time, the first settlers could still migrate to another empty valley. Beggerly argued that the first settlers used tree-fern starch as a food resource because tree fern spores showed an early ebb in her soil core samples.

She found Pandanus pollen in the lagoon phase, which may explain today's presence of the many hala trees on the midslopes of both sides of the valley. Pandanus is usually found in coastal settings near the ocean shore. She also found ebbs in Metrosideros pollen and tree-fern spores alternating with ebbs of Pandanus pollen and concluded that these alternations may be the result of human intervention with Kahana's rain forest. Athens and Ward (1993), doing similar coring studies in Kawainui marsh, showed the startling result of an abundance of Pritchardia (loulu) palm pollen before the first centuries of Polynesian land occupation. They found that the loulu palm pollen began to disappear around 1200 A.D. and suggested disease rather than human-induced fire as the cause. They also hold that loulu palm forest was the dominant lowland vegetation type on windward O'ahu when the first human settlers arrived. Because Patricia Beggerly did not find loulu palm pollen in her corings of Kahana marsh, it seems worthwhile to reinvestigate this area, particularly because loulu palms are still present in Kahana's back valley today. The same applies to koa tree pollen, which was not found by 
Beggerly in her soil cores. However, koa pollen was found by Athens et al. (1992), even in areas that lack Acacia koa today. Athens and Ward (1993) did not dispute Beggerly's early human invasion date but suggested resampling her charcoal findings for comparability with other areas of $\mathrm{O}^{\prime}$ ahu.

\section{Two Paleoecological Land Use Models}

CONTINUOUS SUCCESSION OF HUMAN occupation. Patrick Kirch (2000) provided an interesting theory of a successional sequence of the Hawaiian cultural development. He divides it into four phases: phase 1: from 300 to ca. 600 A.D., the colonization period; phase 2: from 600 to ca. 1100 A.D., the development period; phase 3: from 1100 to ca. 1650, the expansion period; and phase 4: from 1650 to Western contact (1776), the protohistoric period.

During phase 1, the prevailing agricultural technology was shifting cultivation, as still practiced today, for example, in parts of $\mathrm{Va}$ nuatu, Solomon Islands, and New Guinea. Taro irrigation in windward valleys had already begun in the colonization phase. It did not develop into a more widely used agricultural technology until the beginning of the expansion phase, around 1100 A.D. Its greatest sophistication was reached during the protohistoric phase from 1600 to 1800 A.D.

DISCONTINUOUS SUCCESSION OF HUMAN occupation. Patricia Beggerly's (1990) model, based directly on her research in $\mathrm{Ka}$ hana Valley, suggested four different phases, as follows.

Phase 1: Between 400 and 30 в.c., the first human settlement occurred. She suggested that it involved ca. 100 people. They initially used tree-fern starch as a food source while they began swidden cultivation with ti (Cordyline terminalis) and taro (Colocasia esculenta) through opening the forest by cutting it down with subsequent burning of the slash. In so removing the forest on slopes, they caused soil avalanching, which resulted in the accumulation of colluvium in the lagoon phase at the valley bottom. That also destroyed the fish populations in the lagoon. Overexploitation forced the first colonizers to migrate into neighboring valleys. At that time, such valleys may have been unoccupied.

Phase 2: From 30 в.c. to 1200 A.D., Kahana Valley was abandoned. The indigenous forest regenerated. Fewer soil avalanches occurred. The marsh formed by further, mostly organic, terrestrification processes and herbaceous cover dominated on the valley floor.

Phase 3: From 1200 to 1800 the second wave of settlers had arrived. They again started with slash-and-burn agriculture. A second phase of environmental degradation ensued but not for long. This time, the settlers did not move out of Kahana Valley. Because the population had expanded in all windward valleys, space had become limited. In conjunction with swidden cultivation by removing forest for growing crops on dry land, the settlers began irrigation agriculture by constructing wet terraces (the lo $\mathrm{i}$ ) and converting stream water through ditch systems (the 'auwai).

Phase 4: From 1800 to 1900, after Western contact, a third phase of forest degradation began, combined with accelerated erosion. Early in this phase, ca. 1825, as told in written historical accounts, slopes were brown and bare and forest was confined to the inner valley and the upland region. The western slopes were still cultivated in spots with dryland taro, banana, and sweet potato, and the riparian lowlands with irrigated taro in spotty wet terraces. The traditional use changed with overseas immigrants: Eastern agricultural practices of rice growing and Western practices of cattle grazing were introduced. In addition to the free-roaming cattle, other hoofed animals such as goats, sheep, and pigs were using the valley's vegetation. This was followed by sugarcane growing in the pasture area with the Castle-owned $\mathrm{Ka}$ huku Railroad reaching south across Kahana Stream into the eastern valley in the late eighteenth to early nineteenth century. During World War II Kahana Valley was used as a military training area. Remnant bunker structures are still found on the loop trail in the back part of the valley. Related to this is the tragic story of land tenure, the changes in land ownership as discussed earlier. 


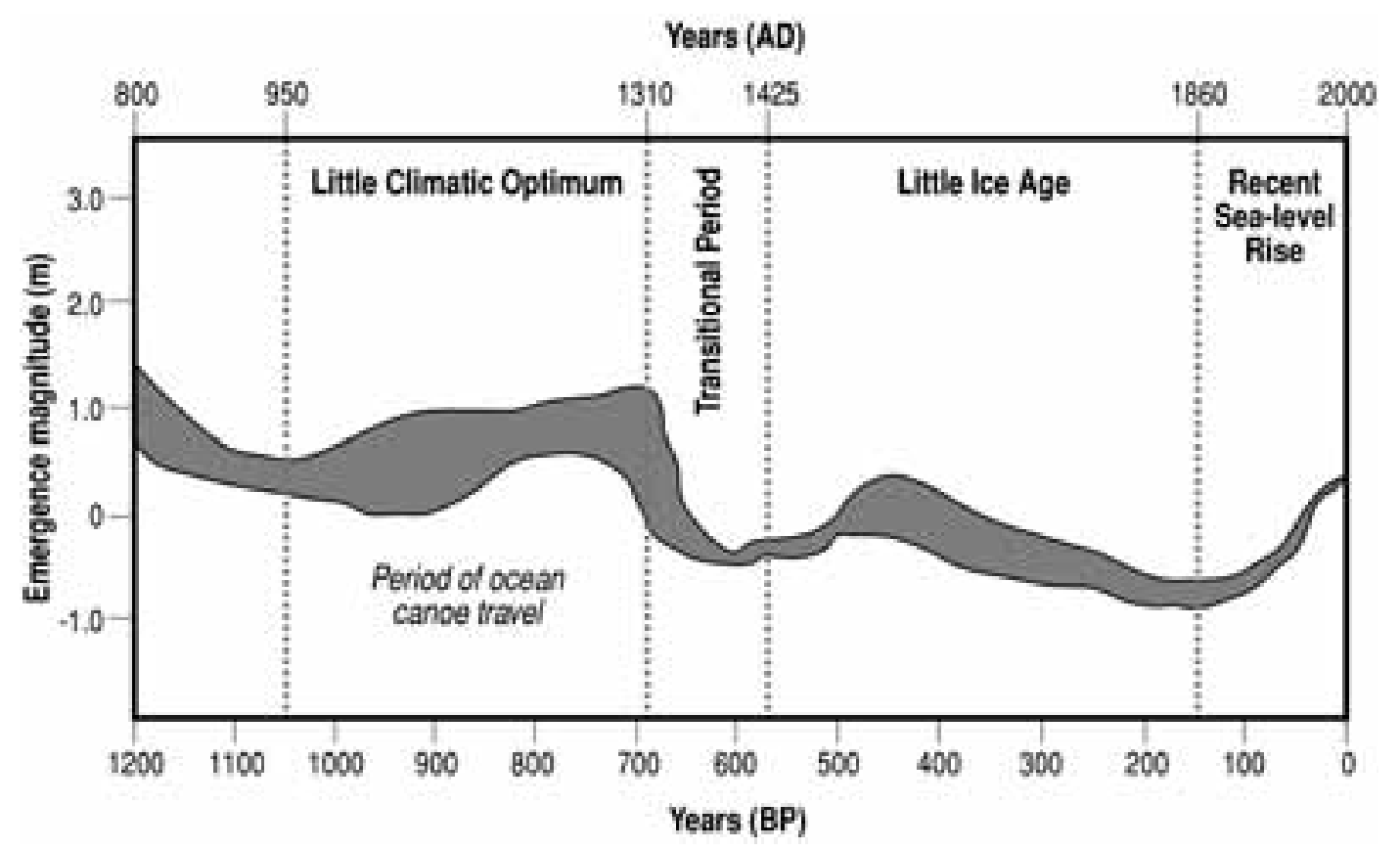

Figure 11. Changes in emergence over the last $1,200 \mathrm{yr}$ as portrayed by Patrick D. Nunn (1999). Reproduced with some additions for clarification and permission by the author.

Sea Level changes. Patrick Nunn's (1999) diagram of sea level changes over the last 1,200 yr (Figure 11) provides further insights. The first human colonization phase certainly had occurred before 800 A.D. (i.e., 1200 в.P.) when the sea level was perhaps $2 \mathrm{~m}$ higher than today. The bottomland of Kahana Valley was then a marine embayment up to the inland margin of the current pasture, or meadow (ca. $1.2 \mathrm{~km}$ inland of the current Kahana beach), as confirmed by $\mathrm{Pa}$ tricia Beggerly (1990). Kahana's inland marine bay changed into a lagoon most likely when the sea level dropped thereafter to about $1 \mathrm{~m}$ above the current level. According to Beggerly's interpretation, the first settlers had already abandoned Kahana Valley due to overexploitation, and the valley was experiencing a fallow period of about 12 centuries until ca. 800 B.P. (i.e., 1200 A.D.). Then the second wave of settlers arrived eight centuries ago, during the "Little Climatic Optimum." They again began to use Kahana Valley by practicing slash-and-burn agriculture. This second group of settlers remained in the valley. They soon changed their land-use practices from degrading the environment to enhancing its natural resources. They accomplished this by developing irrigation schemes and removing stones from dryland terraces for growing newly introduced crop plants, such as sweet potato (Ipomoea batatas, 'uala), as well as by constructing fish traps culminating in the Huilua Fishpond. The latter is said to have been developed about four centuries ago.

According to Patrick Kirch's (2000) successional interpretation of human impact on windward $\mathrm{O}^{6} \mathrm{ahu}$, there was only one phase of settlement. Colonization with slash-andburn practices occurred only once. This was ca. five centuries before the Little Climatic Optimum. During the warmer and calmer climatic phase, when ocean canoe travel was common practice, Kirch's development phase gave way to his expansion phase ca. nine centuries ago. From that time onward, the $\mathrm{Ha}$ waiian land-use practices started to enhance 
the natural ecosystem services through conservation practices. This then became the traditional Hawaiian ahupua'a management system. It existed through the "Little Ice Age," when European sea travel began in the Pacific. At the end of the Little Ice Age, the Hawaiian land-care system collapsed, around 1860 . The reason for that was not climate change. It was primarily the Westernintroduced privatization of land and the cash economy that corrupted the traditional life style and culture of the indigenous Hawaiian people. Jane Allen (1997), who reviewed prehistoric development on windward O'ahu, also related landscape changes to the Little Climatic Optimum and the Little Ice Age. She says that windward valleys were already settled by about 600 A.D., and that human impact upslope was strong during the Little Climatic Optimum. During this period of higher sea level, much erosive material was deposited downhill on marine platforms. Thereafter, terracing began during the Little Ice Age and the irrigation of lo'i began. She concluded that both natural forces and human activity interacted in prehistoric landscape change.

\section{Conclusions}

By synthesizing the former study of Kahana's vegetation ecology with its archaeological and paleoecological investigations, it has become abundantly clear that human impact in the valley has been substantial for at least the past 12 centuries. However, characterization of Kahana Valley as a "geomorphic artifact," as proposed by Beggerly (1990), does not appear to be warranted. The valley's geomorphology certainly has undergone changes. The continued drop of sea level following the postPleistocene warming may be the prime reason for the change of the inland marine bay into a lagoon. Moreover, the terrestrification of the inland lagoon may have become accelerated with the transition period to the Little Ice Age seven centuries ago, when the sea level dropped another meter in roughly 100 yr. Human invasion of the valley during or before the Little Climatic Optimum certainly contributed to landscape change, but it was not the only force. Natural forces were equally apparent, if not of greater importance.

Moreover, Beggerly's (1990) argument that her charcoal find, dated $230 \pm 200 \mathrm{yr}$ B.C., indicates human presence is tenuous. Her argument is based on the assumption that natural fires could not have occurred in this wet rain-forest valley. That argument overlooks the fact that the widespread uluhe fern dries up periodically and surely can serve as an easily combustible material during a dry spell. As Vogl (1969) documented, fire caused by lightning has occurred repeatedly in windward valleys. Also, Mueller-Dombois and Lamoureux (1967) documented the occurrence of past natural fire in Hawai'i before Polynesian land occupation.

The back-valley slopes, occupied by 'ōhi'a lehua (Metrosideros polymorpha) woodland with uluhe fern (Dicranopteris linearis), represent the outcome of a prolonged (ca. 2 million yr) primary succession. As fine soil is formed there from weathering, it also wastes constantly or abruptly away by erosion, thereby keeping the substrate primarily as rockland. Both the 'ōhi'a lehua tree and the uluhe fern invade land scars after soil avalanches. The occurrence of rockland and avalanche scars on slopes maintains a vegetation whose dynamics is arrested in primary succession. This vegetation never reaches a climax state in the sense of Clements $(1916,1928)$. Likewise, the koa and hala tree are native pioneer species that are highly resilient. They regenerate after fire. Thus, native colonizer species dominate the two larger vegetation types in the mid- and back valley. The MetrosiderosDicranopteris back-valley type is resilient to geomorphic instability. The Acacia koaPandanus midvalley type is resilient to human impacts, including an occasional fire. The marsh area in the valley represents an advanced successional stage of a typical hydrarch succession in the Clementsian sense. If swamp tree species had evolved in the Hawaiian flora, as are prevalent in the western Pacific islands (Stemmermann 1981), the marsh would have long become a swamp forest. Such process is currently ongoing with invasion of the octopus tree. Another introduced tree species capable of invading the marsh is the paperbark tree (Melaleuca quin- 
quenervia). It has been planted in Kahana Valley but is not yet documented as naturalized. The current management goal of an arrested wetland succession can still be upheld by tree removal. Currently, efforts are under way to restore the Kahana State Park (recently renamed Ahupua'a 'O Kahana State Park) as a functional ahupua'a. Results of follow-up historical and more complete biodiversity research with PABITRA methodologies will continue to yield helpful information. Such information can be used to support restoration of ecosystem functions and biodiversity components. In addition, new research can be directed to determine if the restored $\mathrm{Ka}$ hana ahupua'a will be able to function as a sustainable system in the future.

\section{ACKNOWLEDGMENTS}

We thank Mark Nakamura for computer drafting the line drawings and Annette Mueller-Dombois for word processing and editorial counseling.

\section{Literature Cited}

Allen, J. 1997. Pre-contact landscape transformation and cultural change in windward O'ahu. Pages 230-247 in P. V. Kirch and T. L. Hunt, eds. Historical ecology in the Pacific islands: Prehistoric environmental and landscape change. Yale University Press, New Haven, Connecticut.

Athens, J. S., and J. V. Ward. 1993. Environmental change and prehistoric Polynesian settlement in Hawai'i. Asian Perspect. 32 (2): 205-222.

Athens, J. S., J. V. Ward, and S. Whickler. 1992. Late Holocene lowland vegetation, O'ahu, Hawai'i. N. Z. J. Archaeol. 14:934.

Beggerly, P. R. 1990. Kahana Valley, Hawai'i, a geomorphic artifact: A study of the interrelationships among geomorphic structures, natural processes, and ancient Hawaiian technology, land use, and settlement patterns. Ph.D. diss., University of Hawai'i at Mānoa, Honolulu.

Clements, F. E. 1916. Plant succession: An analysis of the development of vegetation. Carnegie Institution, Washington.

- 1928. Plant succession and indicators. Republished, 1963. Hafner Publ. Co., New York.

Hommon, R. J., and W. M. Barrera Jr. 1971. Archeological survey of Kahana Valley, Ko'olau District, Island of O'ahu. Department of Anthropology, B. P. Bishop Museum, Honolulu, Hawai'i (prepared for Division of State Parks). Department of Land and Natural Recources Report 71-3. Available from Division of State Parks, State of Hawai'i, Honolulu.

Judd, C. S. 1935. Koa reproduction after fire. J. For. 33:176.

Kirch, P. V. 1985. Feathered gods and fishhooks: An introduction to Hawaiian archaeology and prehistory. University of Hawai'i Press, Honolulu.

-2000. On the roads of the winds: An archaeological history of the Pacific islands before European contact. University of California Press, Berkeley.

Minerbi, L. 1999. Indigenous management models and protection of the ahupua'a. Soc. Process Hawai'i 39:208-225.

Mueller-Dombois, D. 1973. A non-adapted vegetation interferes with soil water removal in a tropical rain forest area in Hawai'i. Trop. Ecol. 24:1-18.

Mueller-Dombois, D., and F. R. Fosberg. 1998. Vegetation of the tropical Pacific islands. Ecol. Stud. 132. Springer-Verlag.

Mueller-Dombois, D., and C. H. Lamoureux. 1967. Soil-vegetation relationships in Hawaiian kipukas. Pac. Sci. 21:286-299.

Nunn, P. D. 1999. Environmental change in the Pacific Basin. Wiley \& Sons, Ltd., Chichester, England.

Palmer, D. D. 2003. Hawai'i's ferns and fern allies. University of Hawai'i Press, Honolulu.

Pukui, M. K., and S. H. Elbert. 1986. Hawaiian dictionary. University of Hawai'i Press, Honolulu.

Puniwai, N. 1997. Decline of Acacia koa on windward O'ahu. Final report. USDA Forest Service, Institute of Pacific Islands Forestry, Honolulu. Available from Division of State Parks, State of Hawai'i, Honolulu. 
Spatz, G., and D. Mueller-Dombois. 1973. The influence of feral goats on koa tree reproduction in Hawai' $i$ Volcanoes National Park. Ecology 54:870-876.

Stauffer, R. H. 1990. Land tenure in Kahana, Hawai'i, 1846-1920. Ph.D. diss., University of Hawai'i, Honolulu.

Stemmermann, L. 1981. A guide to Pacific wetland plants. U.S. Army Corps of Engineers, Honolulu District, Honolulu.

Takasaki, K. J., G. T. Hirashima, and E. R. Lubke. 1969. Water resources of Windward O'ahu, Hawai'i. Geological Survey Water-Supply Paper 1894. Prepared in cooperation with Division of Water and Land Development, Department of Land and Natural Resources, State of Hawai'i. U.S. Government Printing Office, Washington, D.C.

Theobald, W. L., and N. Wirawan. 1973. Kahana Valley botanical survey, Ko'olau
District, island of O'ahu. Department of Botany, University of Hawai'i, Honolulu, Technical Report prepared for Division of State Parks, Outdoor and Historical Sites, Department of Land and Natural Resources, State of Hawai'i, Honolulu. Available from Division of State Parks.

Vogl, R. J. 1969. The role of fire in the evolution of the Hawaiian flora and vegetation. Proc. Tall Timbers Fire Ecol. Conf., 1969: 5-60.

Wagner, W. L., D. R. Herbst, and S. H. Sohmer. 1990. Manual of the flowering plants of Hawai'i. 2 vols. University of Hawai'i Press and Bishop Museum Press, Honolulu.

Wirawan, N. 1978. Vegetation and soil-water regimes in a tropical rain forest valley on O'ahu, Hawaiian Islands. Ph.D. diss., University of Hawai'i at Mānoa, Honolulu.

Appendix

Kahana Valley Plant Checklist

Abutilon grandifolium* (Willd.) Sweet (Malvaceae), ma'o, hairy abutilon

Acacia koa A. Gray (Fabaceae), koa

Adenophorus pinnatifidus Gaudich. (Grammitidaceae), kihi

Adenophorus tamariscinus (Kaulf.) Hook. \& Grev. (Grammitidaceae), wahine noho mauna

Adiantum raddianum C. Presl (Pteridaceae), maidenhair fern

Ageratina riparia* (Reget) R. King \& H. Robinson (Asteraceae), pāmakani

Aleurites moluccana* (L.) Willd. (Euphorbiaceae), kukui

Alocasia macrorrbiza* (L.) Schott (Arecaceae), 'ape

Alyxia oliviformis Gaud. (Apocynaceae), maile, endemic

Amaranthus viridis* L. (Amaranthaceae), pakai

Andropogon virginicus* L. (Poaceae), broomsedge

Antidesma pulvinatum Hillebr. (Euphorbiaceae), hame

Ardisia crenata* Sims (Myrsinaceae), Hilo holly

Ardisia elliptica* Thunb. (Myrsinaceae), shoebutton ardisia

Artocarpus altilis* (S. Parkinson ex Z) Fosb. (Moraceae), 'ulu, breadfruit

Arundina graminifolia* (D. Don) Hochr. (Orchidaceae), bamboo orchid

Bidens pilosa ${ }^{*}$ L. (Asteraceae), kī, kī nehe, Spanish needle Bidens populifolia Sherff (Asteraceae)

Bixa orellana* L. (Bixaceae), 'alaea, annatto, lipstick tree Blechnum appendiculatum Willd. (Blechnaceae)

Brachiaria mutica* (Forssk.) Stapf (Poaceae), Calfornia grass

Broussonetia papyrifera (L.) Vonton. (Moraceae), wauke

Bulbostylis capillaris (L.) C. B. Clarke (Cyperaceae)
Calophyllum inophyllum* L. (Clusiaceae), kamani Canavalia cathartica* Thouars (Fabaceae), maunaloa Carex wahuensis C. A. Mey (Cyperaceae)

Casuarina equisetifolia* L. (Casuarinaceae), paina, ironwood tree

Cenchrus enchinatus* L. (Poaceae), 'ume'alu, common sandbur

Centaurium erythraea* Raf. (Gentianaceae), European centaury

Centella asiatica* (L.) Urb. (Apiaceae), pohe kula, Asiatic pennywort

Chamaecrista nictitans*(L.) Moench (Fabaceae), laukī, partridge pea

Chamaesyce hypericifolia*(L.) Millsp. (Euphorbiaceae), graceful spurge

Charpentiera obovata Gaud. (Amaranthaceae), pāpala

Christella dentata (Forssk.) Brownsey \& Jermy

(Thelypteridaceae), pai'icihā

Chrysopogon aciculatus* (Rets.) Trin. (Poaceae), mānienie 'ula

Cibotium chamissoi Kaulf. (Dicksoniaceae), hāpu'u

Cibotium menziesii Hook. (Dicksoniaceae), hāpu'u 'i'i

Clerodendrum philippinum* Schauer (Verbenaceae), pīkake hohono

Clidemia birta*(L.) D. Don (Melastomataceae), Koster's curse

Cocculus trilobus (Thunb.) DC (Menispermaceae), huehue

Coix lachryma-jobi* L. (Poaceae), pū'ohe'ohe, kūkaekōlea, Job's tears

Colocasia esculenta* $^{*}$ (L.) Schott. (Araceae), kalo, taro 
Appendix (continued)

\begin{tabular}{|c|c|}
\hline $\begin{array}{l}\text { Commelina diffusa* N. L. Burm. (Commelinaceae), } \\
\text { honohono, honohono wai }\end{array}$ & $\begin{array}{l}\text { Ipomoea indica (J. Burm.) Merr. (Convolvulaceae), koali } \\
\text { 'awa }\end{array}$ \\
\hline Convolvulus arvensis* L. (Convolvulaceae), field bindweed & Ipomoea pes-caprae (L.) R. Br. (convolvulaceae) pōhuehue \\
\hline $\begin{array}{l}\text { Conyza canadensis* (L.) Cronq. (Asteraceae), lani wela, } \\
\text { Canada fleabane }\end{array}$ & $\begin{array}{l}\text { Korthalsella latissima (Tiegh.) Degener (Viscaceae), } \\
\text { kaumahana, mistletoe }\end{array}$ \\
\hline $\begin{array}{l}\text { Cordyline fruticosa* (L.) A. Chev. (Agavaceae), ti } \\
\text { Coronopus didymus* (L.) Sm. (Brassicaceae), swinecress }\end{array}$ & $\begin{array}{l}\text { Kyllingia nemoralis* (J. R. Forster \& G. Forster) Dandy } \\
\text { (Cyperaceae), kili'o'opu }\end{array}$ \\
\hline $\begin{array}{l}\text { Crotalaria pallida* Aiton (Fabaceae), pikakani, smooth } \\
\text { rattlebox }\end{array}$ & $\begin{array}{l}\text { Lantana camara* L. (Verbenaceae), lākana } \\
\text { Lepisorus thunbergianus (Kaulf.) Ching (Polypodiaceae), }\end{array}$ \\
\hline $\begin{array}{l}\text { Cuphea carthagenensis* (Jacq.) Macbr. (Lythraceae), } \\
\text { tarweed }\end{array}$ & $\begin{array}{l}\text { pākahakaha } \\
\text { Leucaena leucocephala* (Lam.) de Wit (Fabaceae), koa }\end{array}$ \\
\hline Cuscuta sandwichiana Choisy (Cuscutaceae), kauna'oa, & $\begin{array}{l}\text { haole } \\
\text { Ludwioig octivalvis*(Jaca) Raven (Onaoraceae) kāmo }\end{array}$ \\
\hline $\begin{array}{l}\text { Cyclosorus interruptus (Willd.) H. Ito (Thelypteridaceae), } \\
\text { neke }\end{array}$ & \\
\hline Cyperus rotundus* L. (Cyperaceae), kili'o'opu, nutgrass & wāwaeciole \\
\hline $\begin{array}{l}\text { Cyrtandra bawaiiensis C. B. Clark (Gesneriaceae), } \\
\text { ha'iwale }\end{array}$ & $\begin{array}{l}\text { Machaerina angustifolia (Gaud.) T. Koyama (Cyperaceae), } \\
\text { 'uki }\end{array}$ \\
\hline Cyrtandra laxiflora H. Mann (Gesneriaceae) & Mangifera indica* L. (Anacardiaceae), manakō, mango \\
\hline Cyrtandra spp., endemic & Mecodium recuroum (Gaudich.) Copel. \\
\hline $\begin{array}{l}\text { Dicranopteris linearis (Burm. f.) Underw. } \\
\text { (Gleicheniaceae), uluhe }\end{array}$ & $\begin{array}{l}\text { (Hymenophyllaceae), 'ōhi'a kū, filmy fern } \\
\text { Melaleuca quinquenervia' (Car.) S. T. Blake (Myrtaceae), }\end{array}$ \\
\hline Dioscorea bulbifera* L. (Dioscoreaceae), hoi, bitter yam & paperbark tree \\
\hline $\begin{array}{l}\text { Dioscorea pentaphylla* L. (Dioscoreaceae), pi'a, yam } \\
\text { Diospyros sandwicensis (A. DC) Fosb. (Ebenaceae), lama }\end{array}$ & $\begin{array}{l}\text { Metrosideros polymorpha Gaud. (Myrtaceae), 'ōhi`a lehua, } \\
\text { endemic }\end{array}$ \\
\hline $\begin{array}{l}\text { Diplazium sandwichianum (C. Presl) Diels (Athyriaceae), } \\
\text { hō'i'o }\end{array}$ & $\begin{array}{l}\text { Metrosideros tremuloides (A. Heller) P. Knuth } \\
\text { (Myrtaceae), lehua 'âhihi }\end{array}$ \\
\hline $\begin{array}{l}\text { Diplopterygium pinnatum (Kunze) Nakai } \\
\text { (Gleicheniaceae), uluhe lau nui }\end{array}$ & $\begin{array}{l}\text { Mimosa pudica* L. (Fabaceae), pua hilahila, sensitive } \\
\text { plant }\end{array}$ \\
\hline $\begin{array}{l}\text { Doryopteris decipiens (Hook.) J. Sm. (Pteridaceae), } \\
\text { 'iwa'iwa }\end{array}$ & $\begin{array}{l}\text { Morinda citrifolia }{ }^{*} \text { L. (Rubiaceae), noni, Indian mulberry } \\
\text { Myrsine lessertiana A. DC (Myrsinaceae), kōlea lau nui }\end{array}$ \\
\hline Dryopteris spp. (Dryopteridaceae), olua & Nephrolepis multiflora (Roxb.) F. M. Jarrett ex C. V. \\
\hline $\begin{array}{l}\text { Elaeocarpus bifidus Hook. \& Arnott (Elaeocarpaceae), } \\
\text { kalia }\end{array}$ & $\begin{array}{l}\text { Morton (Nephrolepidaceae) } \\
\text { Nestegis sandwicensis (A. Gray) Degener (Oleaceae), }\end{array}$ \\
\hline $\begin{array}{l}\text { Elaphoglossum aemulum (Kaulf.) Brack. } \\
\text { (Lomariopsidaceae), ‘êkaha }\end{array}$ & $\begin{array}{l}\text { olopua } \\
\text { Ochrosia compta K. Schum. (Apocynaceae) }\end{array}$ \\
\hline $\begin{array}{l}\text { Elaphoglossum crassifolium (Gaudich.) W. R. Anderson \& } \\
\text { Crosby (Lomariopsidaceae), 'ēkaha }\end{array}$ & $\begin{array}{l}\text { Ophioglossum polyphyllum A. Braun (Ophioglossaceae), } \\
\text { pololei, adder's tongue }\end{array}$ \\
\hline Emilia fosbergii* Nicolson (Asteraceae), pualele & Oplismenus birtellus ${ }^{*}$ (L.) P. Bear. (Poaceae), honohono, \\
\hline $\begin{array}{l}\text { Emilia sonchifolia* (L.) DC (Asteraceae), Flora's } \\
\text { paintbrush }\end{array}$ & $\begin{array}{l}\text { basketgrass } \\
\text { Osteomeles anthyllidifolia (Sm.) Lindl. (Rosaceae), 'ūlei }\end{array}$ \\
\hline $\begin{array}{l}\text { Erechtites valerianifolia* (Wolf) DC (Asteraceae) } \\
\text { Eucalyptus* }^{*} \text { sp. (Myrtaceae) }\end{array}$ & $\begin{array}{l}\text { Pandanus tectorius S. Parkinson ex Z (Pandanaceae), hala } \\
\text { tree }\end{array}$ \\
\hline Fimbristylis dichotoma (L.) Vahl (Cyperaceae) & Panicum maximum* Jacq. (Poaceae), Guinea grass \\
\hline Freycinetia arborea Gaud. (Pandanaceae), 'ie'ie & Paraserianthes falcataria* (Fabaceae), albizia \\
\hline $\begin{array}{l}\text { Gardenia mannii St. John \& Kuykendall (Rubiaceae), } \\
\text { nānū }\end{array}$ & $\begin{array}{l}\text { Paspalum conjugatum* Bergius (Poaceae), Hilo grass } \\
\text { Paspalum scrobiculatum }{ }^{*} \text { L. (Poaceae), mau'u laiki, }\end{array}$ \\
\hline Gonocormus minutus (Blume) Bosch (Hymenophyllaceae) & \\
\hline Grammites tenella Kaulf. (Grammitidaceae), kolokolo & Paspalum urvillei* Steud. (Poaceae), Vasey grass \\
\hline $\begin{array}{l}\text { Hedychium coronarium* }{ }^{*} \mathrm{~J} \text {. König (Zingiberaceae), } \\
\text { 'awapuhi ke'oke'o, white ginger }\end{array}$ & $\begin{array}{l}\text { Passiflora edulis* Sims (Passifloraceae), passion fruit, } \\
\quad \text { liliko' } \mathrm{i}\end{array}$ \\
\hline $\begin{array}{l}\text { Hedychium flavescens* } \mathrm{N} \text {. Carey ex Roscoe } \\
\text { (Zingiberaceae), 'awapuhi melemele, yellow ginger }\end{array}$ & $\begin{array}{l}\text { Passiflora foetida }{ }^{*} \text { L. (Passifloraceae) pohāpohā, wild } \\
\text { water lemon }\end{array}$ \\
\hline $\begin{array}{l}\text { Hibiscus arnottianus A. Gray (Malvaceae), koki'o ke'oke‘o } \\
\text { Hibiscus tiliaceus L. (Malvaceae), hau }\end{array}$ & $\begin{array}{l}\text { Passiflora mollisima* (Kunth) L. H. Bailey } \\
\text { (Passifloraceae), banana poka }\end{array}$ \\
\hline $\begin{array}{l}\text { Huperzia phyllantha (Hook. \& Arn.) Holub } \\
\text { (Lycopodiaceae), wāwae'iole, rat's foot }\end{array}$ & $\begin{array}{l}\text { Passiflora pulchella* Kunth (Passifloraceae), two-lobed } \\
\text { passion flower, naturalized }\end{array}$ \\
\hline $\begin{array}{l}\text { Ipomoea alba* L. (Convolvulaceae), koali pehu, moon } \\
\text { flower }\end{array}$ & $\begin{array}{l}\text { Passiflora suberosa* L. (Passifloraceae), huehue haole, } \\
\text { introduced; wild passion flower }\end{array}$ \\
\hline
\end{tabular}


Appendix (continued)

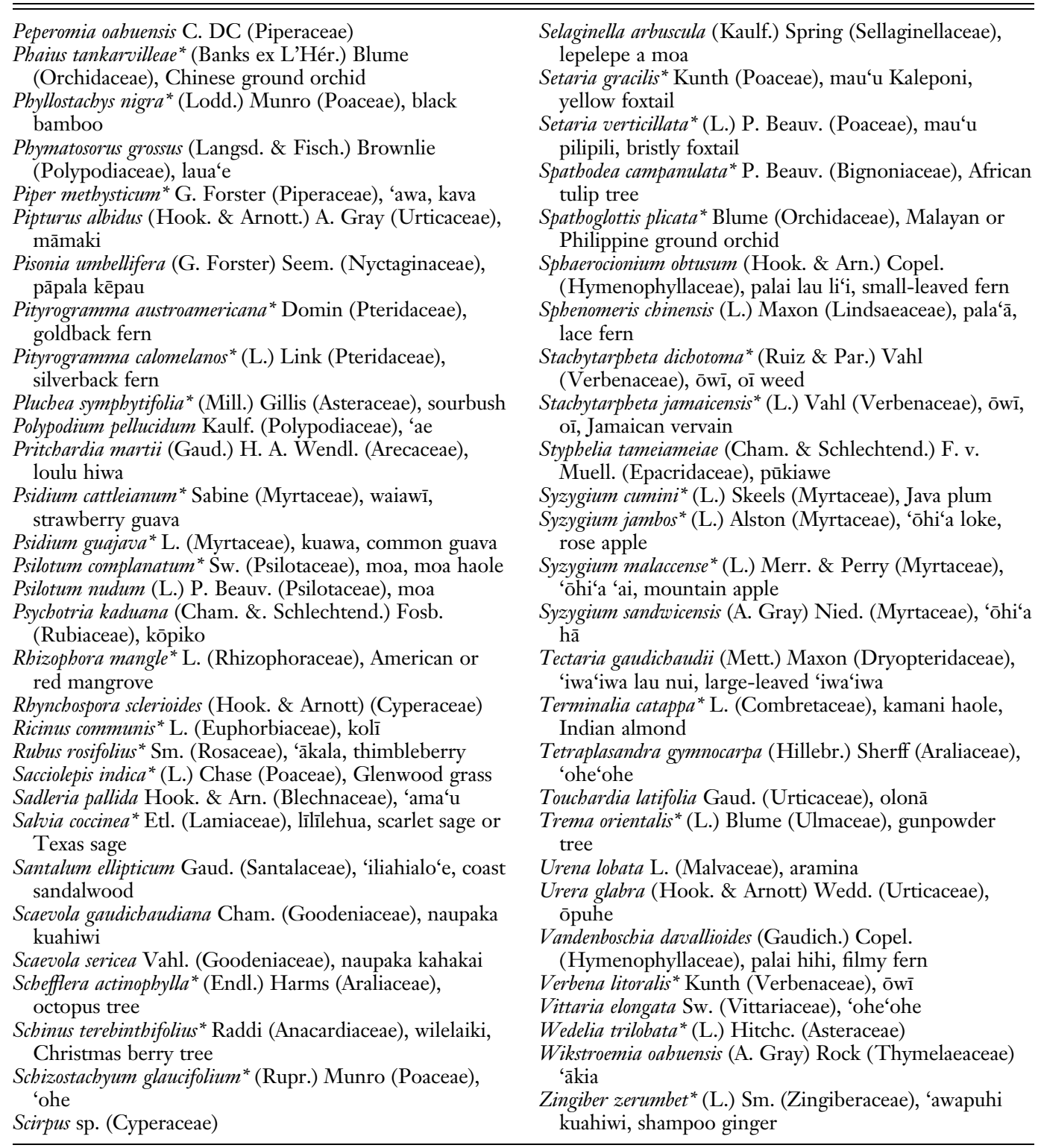

Note: After Wirawan (1978); updated by D.M.-D. in 2003. Names are from Wagner et al. (1990) and Palmer (2003).

* Nonnative. 